\title{
French agency plans biomedical reformation
}

\section{Sally Goodman, Paris}

Researchers at INSERM, France's biomedical research agency, are being offered more money to establish partnerships with outside universities, hospitals and industry.

At the same time, the agency is trying to reform its relationships with partner organizations inside and outside the government, says Christian Bréchot, INSERM's director. He adds that the reforms may lay the foundations for an entirely new structure for French biomedical research.

This autumn, Bréchot will launch a programme of five-year "interface" contracts for INSERM researchers. These are designed to increase mobility between the agency's labs and external partners. Under the contracts, the researchers will keep their civil-service status and salary, but they will receive an extra 1,500 euros (US\$1,450) a month from one of the partners. In parallel, the partner organizations will run a similar scheme to allow their staff to spend some time in an INSERM lab, with some of the costs of temporarily replacing these staff being covered by INSERM.

"In France, mobility is still often associated with failure rather than career progression," says Bréchot. "That needs to change. This model will combine the security of tenure

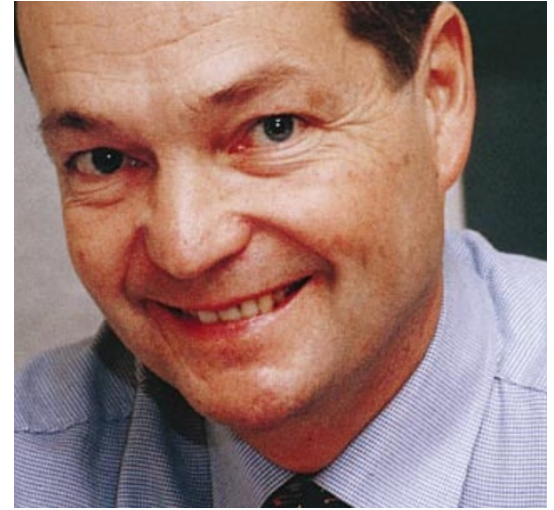

Harbinger of change: Christian Bréchot wants to increase mobility among French researchers.

track with the flexibility and stimulation of working with other partners." He hopes that 600-800 of INSERM's 3,000 researchers will be working under the new contracts by 2006 .

Bréchot, a hepatitis specialist who took charge of INSERM in February 2001, has already reduced the mandate of the agency's laboratories from 12 to 8 years, with an evaluation every four years. He says that he is now looking at the US National Institutes of Health (NIH) as a model, and wants to start discussions about creating national "institutes without walls" for cancer, infectious diseases, cardiovascular research, and rare diseases and medical genetics. These would promote more efficient collaboration between researchers from INSERM and other research agencies, he says.

Bréchot's actions could pave the way for a much broader reform of biomedical research in France. The idea of a single, NIH-type agency for life sciences has been talked about in France for more than 20 years. Bréchot believes that the time is ripe for action, and plans to talk to colleagues at other research agencies about the project's feasibility. $\mathrm{He}$ says that if the idea is well received, a new agency could see the light of day within four years.

A 1998 attempt to reform INSERM was shelved after opposition from researchers' unions (see Nature 395, 630; 1998). This time the unions, although they accept some of Bréchot's arguments, have accused him of not making sufficient use of INSERM's consultative bodies before making decisions.

But Philippe Kourilsky, director of the Pasteur Institute in Paris, which hosts many INSERM researchers, says Bréchot deserves scientists' support. "Researcher mentality has evolved, and the best aren't interested in a job for life any more," he says.

\section{Hologram technique to flush out features of bog body}

\section{Alison Abbott, Munich}

The faces of the ancients are about to be revealed using a toolbox of techniques created by surgeons and engineers.

A team of archaeologists and anthropologists at an interdisciplinary research centre in Germany is using the imaging techniques to reconstruct the features of a 2,000-year-old body.

Found in 1936 in a bog in Lower Saxony, the body's soft tissues have been well

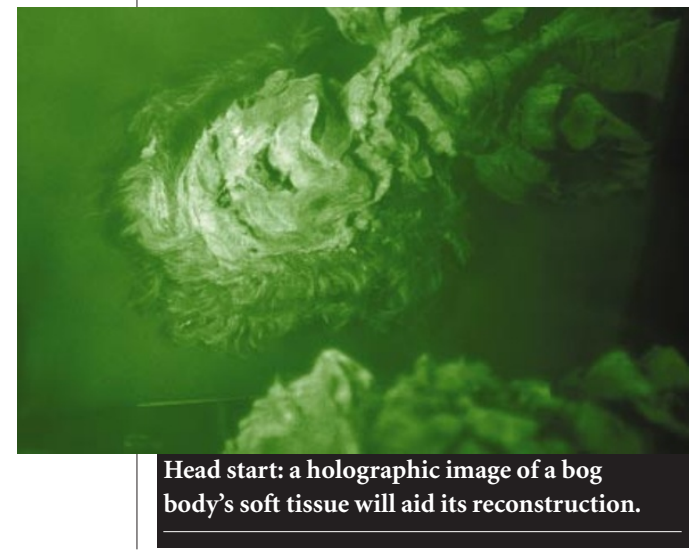

preserved by its stay in the swamp. This is the result of the dehydrating effects of tannic acid, as well as the presence of sphagnum moss in the bog, which hinders decomposition.

The researchers at Caeser, the Center of Advanced European Studies and Research, in Bonn are using computer tomography to get a three-dimensional image of the body's hard tissue, and holography to image the surface of its soft tissues.

Peter Hering, a physicist at the University of Düsseldorf who works at Caeser, first developed the holographic techniques for reconstructing congenitally malformed faces using laser surgery. But in June, he contacted Mamoun Fansa, director of the Oldenburg Nature and Folk Museum, which holds five 'bog bodies' dating back to Roman times. They decided to transfer one of the bodies to Bonn for imaging analysis.

Data from the two analyses are now being merged to create a physical replica of the body, using some prototyping techniques borrowed from the engineering industry. The final reconstruction based on the replica will be crafted by the company Atelier Daynes in Paris, which specializes in making sculptures of palaeoanthropological specimens.

Reconstructions of ancient bodies based on computer tomography have been done before, but not with the advantage of data on soft tissue, says Hering. "The highprecision sets of data that we have generated will allow the artists to work more accurately and less fancifully," he says.

"Little is known about what humans looked like in the period $300 \mathrm{BC}$ to $\mathrm{AD} 300$ because bodies tended to be burned," says Fansa. Bog bodies are an exception - at least 20 such bodies, thought to be victims of sacrificial rituals, are held by various museums in northern Europe. By studying their faces, historians hope to gain clues as to whether they are Roman or German. Fansa also plans to use DNA analysis to try to resolve this question.

Hering and Fansa are keen to extend the study if the initial analysis works well. Hering says he would like to be able to make holograms of any newly discovered bodies before they are exhumed. The scientists add that the hologram technique will allow other museums to display virtual, life-sized bog bodies. 